Article

\title{
Business Support for Refugee Integration in Europe: Conceptualizing the Link with Organizational Identification
}

\author{
Yijing Wang * and Vidhi Chaudhri \\ Department of Media and Communication, Erasmus University Rotterdam, 3062 PA Rotterdam, The Netherlands; \\ E-Mails: y.wang@eshcc.eur.nl (Y.W.), chaudhri@eshcc.eur.nl (V.C.) \\ * Corresponding author
}

Submitted: 12 December 2018 | Accepted: 16 May 2019 | Published: 28 June 2019

\begin{abstract}
The ongoing refugee crisis presents a plethora of challenges and requires systematic contributions from public and private entities-e.g., governments, non-governmental organizations, community organizations and businesses. Relative to the other three, (explicit) business efforts toward refugee (economic) integration are yet sporadic, limited to a few large organizations. While acknowledging that integration encompasses multiple spheres and is complicated by national and local variations across EU member states, this conceptual article treats business support of refugee (economic) integration as a manifestation of corporate social responsibility (CSR) and contends that such efforts may enhance employee-organizational identification. Drawing on scholarship from CSR and organization-employee identification, we develop a conceptual model including propositions about mediating and moderating mechanisms of the relationship among refugee integration, CSR communication and employee-organizational identification. Our study offers a conceptual bridge between what is known about the importance, barriers and enablers of refugee labor market integration with the lesser-known organizational, specifically employee, perspectives on the issue. Leveraging on this conceptual framework, further research may focus on testing the relationship empirically through collecting field data from business firms which have made an explicit claim on refugee support.
\end{abstract}

\section{Keywords}

business; company; corporate communication; corporate social responsibility; employees; organizational identification; refugee integration

Issue

This article is part of the issue "Refugee Crises Disclosed: Intersections between Media, Communication and Forced Migration Processes", edited Vasiliki Tsagkroni (Leiden University, The Netherlands) and Amanda Alencar (Erasmus University Rotterdam, The Netherlands).

(C) 2019 by the authors; licensee Cogitatio (Lisbon, Portugal). This article is licensed under a Creative Commons Attribution 4.0 International License (CC BY).

\section{Introduction}

In December 2018, the LEGO Foundation announced a \$100 million commitment to the Sesame Workshop (makers of Sesame Street) to develop play-based learning programs for children affected by the ongoing refugee crisis, particularly Syrian and Rohingya refugees (Zraick, 2018). The IKEA Foundation's "Brighter Futures" initiative aims to support Syrian refugee by providing (solar) power and electricity to refugee camps which, in turn, enables a range of seemingly mundane tasks such as food preservation, street safety and children's education, among others. Others such as Deutsche Telekom set up a dedicated task force already in 2015 to enable refugee labor market integration and continue to provide apprenticeships and internships, reportedly offering 420 positions to refugees in 2018 alone. At the EU level, 2017 saw the launch of the European Commission's "Employers Together for Integration" initiative aimed at urging business organizations "including large companies, SMEs 
and public employers" to support refugee integration in the labor market and giving more visibility to such efforts (European Commission, 2017).

These initiatives illustrate a few ways in which leading global business firms are contributing to alleviating the ongoing refugee crisis in Europe. Aside from launching independent initiatives, some (e.g., Unilever, BMW, SAP) have also partnered with humanitarian organizations such as the International Rescue Committee to support refugees in manifold ways including "hiring refugees, speaking out for refugees and creating products and services tailored to their needs" (The International Rescue Committee, n.d.). However, these efforts are only the tip of the iceberg. The scale of the refugee crisis in Europe necessitates long-term, multi-stakeholder solutions. We argue that relative to governments, non-governmental organizations (NGOs), and/or community organizations, businesses have-with notable exception-been on the sidelines of the conversation. Moreover, there is no formalized or regulatory imperative, yet, for businesses to actively support refugee integration and many efforts remain largely sporadic and relief-based as opposed to systemic, long-term solutions targeting refugee integration (loannou, 2015).

Premised on the importance of refugee integration, this article offers a multilevel conceptual framework to advance the goal of business participation in the conversation. First, following Scholten et al. (2017), we acknowledge that "integration" itself is a contested and multi-faceted term including different spheres such as economic, social, health, education, housing, etc. Unlike legal reforms that fall squarely in the government domain, efforts toward integration are seen as a multistakeholder imperative that requires "the close support and co-ordination of governing structures at the national, regional and municipal levels" (OECD \& UNHCR, 2018, p. 5). While efforts to socially and culturally integrate are indeed the steppingstone and the priority for civil society, we concern ourselves with integration primarily in economic terms, i.e., access to employment and the labor market, skill development, etc. Here, the role(s) of business and the private sector assume importance.

Second, even as our article makes the case for business involvement in supporting and advancing refugee integration in the labor market, we should note that such efforts can take diverse forms, from "offering opportunities, valuing and further developing skills and competences and facilitating the creation of an inclusive workplace" (European Commission, 2017). Further, it is important to note that arguments for business involvement in the refugee crisis are often riddled with tensions attributable, among others, to differences in labor market structures and policy context across EU countries (e.g., Scholten et al., 2017) and skeptical public opinion (e.g., OECD \& UNHCR, 2016). Extant surveys confirm that even when businesses are "enthusiastic" or "interested" in employing refugees, they are often deterred by "misperceptions about refugees or lack information relating to their potential as prospective employees. Many seek legal and regulatory guidance around employing refugees" (Betts \& Buith, 2017, p. 5).

Third, we conceptualize business support and efforts toward refugee integration as a manifestation of corporate social responsibility (CSR), broadly defined as "context-specific organizational actions and policies that take into account stakeholders' expectations and the triple bottom line of economic, social and environmental performance" (Rupp \& Mallory, 2015, p. 212). Variously labeled as sustainability, citizenship, corporate responsibility, etc., CSR may take a diversity of forms from philanthropy to producing quality products and services, employee welfare, education, community involvement and so on. More recently, the establishment of the Sustainable Development Goals (Agenda 2030), ratified by all UN member states, has provided a transnational imperative for businesses to play a vital role, together with other institutional actors, in solving grand societal challenges.

Despite the growing import of CSR across disciplines, its relevance for the ongoing refugee crisis has not been explored. Evidence (e.g., OECD \& UNHCR, 2018) suggests that supporting refugee integration as a specific manifestation of CSR is not unprecedented. However, complicating economic support for refugees are a multitude of factors including attitudes and expectations, legal ambiguity, costs and business incentives and matching skills and qualifications (OECD \& UNHCR, 2016). Particularly from a CSR standpoint, research suggests that not all CSR efforts are created equal. In other words, companies are often advised to stick to CSR issues that are related to their core business and/or most strategically important for their business if they are to reap the benefits of doing well and doing good (e.g., Serafeim, 2015).

Given the aforementioned complexities surrounding refugee integration (and elaborated in the next section), supporting refugee integration as a form of CSR necessitates more complex theorizing about the role of business. Our article seeks to respond to this challenge by employing a multilevel perspective outlining the relationship among refugee integration, CSR communication and organization-employee identification. These interlinkages, we contend, may be decisive in shifting refugee support as CSR from a discretionary and ad-hoc activity to a more sustainable approach, embedded in organizational culture. Attending to the perspective of employees is especially meaningful for although CSR activities are conducted for and by corporations, it is the employees "who advocate for, comply with and participate in CSR" (Rupp \& Mallory, 2015, p. 212).

Coupled with the support of employees is the importance of communicating CSR efforts. If business firms intend to achieve legitimacy by supporting refugee employment and integration, they need to communicate this endeavor to their employees proactively and effectively. In other words, refugee integration as a CSR activity must be integrated into the organizational diversity culture"seen as not simply 'talking the talk', but rather 'walking 
the walk'" (Brunton, Eweje, \& Taskin, 2015, p. 32). After all, although refugee employment and integration may heavily depend on the aspiration of managers, the employees are the internal stakeholders who translate this vision into their daily actions. The support of employees is therefore integral to the (newly formed) culture of a business firm (Hatch \& Schultz, 2004).

To unpack our argument, we start by mapping out the current, relevant, arguments surrounding the role of business as an important societal actor in the ongoing refugee crisis, paying specific attention to the challenges and opportunities for business involvement in refugee (economic) integration. Within this macro context, we propose a conceptual model to theorize the relationship among refugee support (as a CSR effort), CSR communication and organizational identification with respect to business firms explicitly claiming their support for refugee integration in Europe.

\section{The Role for Business in Refugee (Economic) Integration}

As previously noted, integration has become both a key policy objective related to the resettlement of refugees and a matter of significant public discussion. Among the research conducted regarding refugee integration, Ager and Strang (2008) identified employment as a key area of activity in association with refugee integration in the public arena. As one of their refugee interviewees put it: "To me integration is work, if we work, we are integrated" (Ager \& Strang, 2008, p. 170). Undoubtedly, for refugees who are inclined to integrate to local community, employment has an important impact on many issues related to them, from promoting economic independence, planning for the future, meeting members of the host society (e.g., colleagues at workplace), providing opportunity to develop language skills, to restoring self-esteem and encouraging self-reliance (Tomlinson \& Egan, 2002). Employment, as a result, is not only a direct route to integration, but also the driving force of public confidence on immigration and integration systems, not to mention the long-term sustainability of welfare systems which depends on a greater number of newcomers entering work quickly (Ager \& Strang, 2008).

The engagement of business firms in refugee integration is not without a reason. Narratives in favor of business involvement range from leveraging a ready source of talent and partnering public organizations in finding collaborative (policy) solutions to business responsibility in shaping societal attitude and perception toward refugees (Marcus, 2015). Further, it has been argued that diversity can lead to a stronger workforce where employees can share and learn from each other (Koser, 2013). Also, hiring refugees is believed to enhance global competitiveness and allow companies to address labor shortages and specific skill needs. Koser (2013) found that refugee employees often display stronger loyalty towards their employer as opposed to other employ- ees, due to higher motivation. Additionally, governments can hardly solve complex social challenges alone and initiatives driven by non-governmental actors, such as business firms, are more likely to be seen as a collective project rather than something imposed from above (Vision Europe Summit, 2016). Harnessing the energy and enthusiasm of employers (e.g., business firms) is therefore critical both to the long-term resilience and well-being of societies and to ensuring that significant government investment in newcomers bear fruit. Small wonder, then, that policymakers encourage business firms to see hiring refugees as a business-savvy proposition aligned with the long-term economic interests of employers.

Co-existing with the business case is the ethical perspective that "addressing the refugee crisis is as much about sustainable growth as it is about respecting and defending human rights" (Unilever, 2017). In their report titled Refugees and Migrants: An Opportunity for Humanity, the B-Team (2016) urges business to reframe the refugee crisis as an opportunity. An excerpt from the report highlights the manifold benefits of such a perspective:

Welcoming refugees is not only a humanitarian and legal obligation; it is an investment that can yield significant economic dividends. Indeed, investing one euro in refugee assistance can yield nearly two euros in economic benefits within five years.... Refugees contribute economically in many ways: as workers, entrepreneurs, innovators, taxpayers, consumers and investors. Their efforts can help create jobs, raise the productivity and wages of local workers, lift capital returns, stimulate international trade and investment and boost innovation, enterprise and growth. (B-Team, 2016, p. 5)

On the flip side, some have argued that business involvement is complicated by and highly contingent on national policies, given that the EU is not a unitary entity. Business initiatives for economic integration may be derailed in the face of unfavorable government policies toward refugees, legal uncertainties, and/or by societal pressure especially if providing jobs is viewed as the loss of local employment opportunities (loannou, 2015). Other reports confirm that initial language barriers, uncertainty about rules and regulations and skeptical public opinion are perceived impediments in business efforts toward recruitment and integration (e.g., OECD \& UNHCR, 2016). Confounding this picture are the volatile perceptions of refugees, triggered by specific incidents and/or negative mediatized images such as those surrounding the violence in Cologne, Germany, and/or the emergence of anti-immigration movements in many EU states (Scholten et al., 2017) that further impede refugee integration.

The preceding discussion highlights arguments in favor of and against refugee support by businesses. While 
desirable in principle, the case for business involvement in refugee integration is complicated by several factors ranging from policy variation across $\mathrm{EU}$ member states to societal attitudes to the pragmatic concerns of language proficiency, qualifications and skills. Not undermining the need for holistic, multi-stakeholder, solutions, our article focuses on theorizing a central role for business firms. In doing so, we seek to offer a conceptual bridge between what is known about the importance, barriers and enablers of refugee labor market integration with the lesser-known organizational, specifically employee, perspectives on the issue. Whether organizational members support their employer's stance on refugee integration may be decisive both for employee attitudes towards the organization as well as the employer's ability to accomplish its objectives of supporting refugees.

In our next section, we outline the links between refugee integration (as a form of CSR) and employeeorganizational identification. We hypothesize that employee alignment and support is critical to finding sustainable solutions for business involvement in the refugee crisis especially in the face of perceived risks identified in the sections above. Guided by the need to incorporate the employee perspective, we theorize the relationship among refugee support (as a CSR effort), CSR communication and organizational identification with respect to business firms explicitly claiming their support for refugee integration in Europe.

\section{CSR, Employees and Organizational Identification}

Like integration, CSR is an "essentially contested concept" (Okoye, 2009). Albeit a contested construct, CSR broadly refers to the role(s) of business in society and can take varied forms from environmental sustainability to supporting diversity to providing quality products and services. The European Commission (2011) defines CSR as a company-led effort to take "responsibility for their impact on society" via legal compliance and by "integrating social, environmental, ethical, consumer and human rights concerns into their business strategy and operations". Being socially responsible is purported to yield tangible business benefits in the form of a positive reputation, customer loyalty and advocacy, financial performance, employee recruitment and retention and organizational commitment, among others (see Carroll \& Shabana, 2010). Indeed, survey data confirm CSR as a primary motivation among a majority $(80 \%)$ of employers that reported hiring refugees in 2017 (OECD \& UNHCR, 2018).

CSR is also a draw for (potential) employees. According to a Nielsen study from 2014, $67 \%$ of respondents reportedly prefer to work for socially responsible companies and this dynamic is often more accentuated among Millennials (Deloitte, 2017). In particular, Millennials not only actively consider CSR in their employment decisions, but three-fourth would reportedly take a pay cut to work with a socially responsible com- pany (Cone Communications, 2016). While these indicators affirm the import of employee support for CSR, previous studies also point to differences in employee attitudes toward CSR attributable to personal priorities (e.g., career development), workplace experiences, academic background and the nature and importance of their work in the organization (e.g., Rodrigo \& Arenas, 2008).

So how might organizational support of refugees as a specific form of CSR influence employee identification with their employer? Employee identification with their employer is a perception of oneness with or belongingness to an organization (Mael \& Ashforth, 1992; Riketta, 2005). The social identity theory (Turner, Brown, \& Tajfel, 1979) suggests that employees may define themselves in terms of their organization (Dutton, Dukerich, \& Harquail, 1994). For example, a key feature of identification is emphasized by Bauman and Skitka (2012) as the value congruence between stakeholders and an organization. Podnar, Golob and Jančič (2011) point out that identification not only comprises identification with the corporate identity, but also with the collective of individuals with whom employees work. To achieve a high identification, employees' value proposition should be aligned with that of the organization.

In the refugee crisis context, employees who believe in the value of refugee integration the same as their employer in promoting societal peace and stability are more likely to commit to their organization. Such an identification may occur in the business that explicitly state their support of refugee integration in alignment with their proactive engagement in, for example, enhancing diversity at the workplace. Once employees identify strongly with their organization, they view its successes as their own, which further determines their self-image (Bhattacharya, Sen, \& Korschun, 2007). Indeed, HaskiLeventhal, Roza and Meijs (2017) argue that overlooking employee engagement in CSR may oversimplify the situation, as the congruence between employees and organizations with regard to this issue may lead to deterministic impact on possible outcomes. Likewise, a high employeremployee congruence on refugee integration, if realized, can generate several positive outcomes in the workplace, such as higher level of job satisfaction and employee identification. So how might organizations accomplish this goal and what are the factors need to be considered?

\section{Theoretical Prediction, Propositions and Conceptual Model}

Our conceptual model (see Figure 1) outlines the relationship among refugee integration, CSR communication and organizational identification.

A previously mentioned, engaging employees in refugee integration (as a form of CSR) is vital if businesses aim for long-term solutions. A key challenge here may stem from the low awareness of a company's CSR activities among its internal stakeholders in general. Recent studies show that CSR awareness is typically 


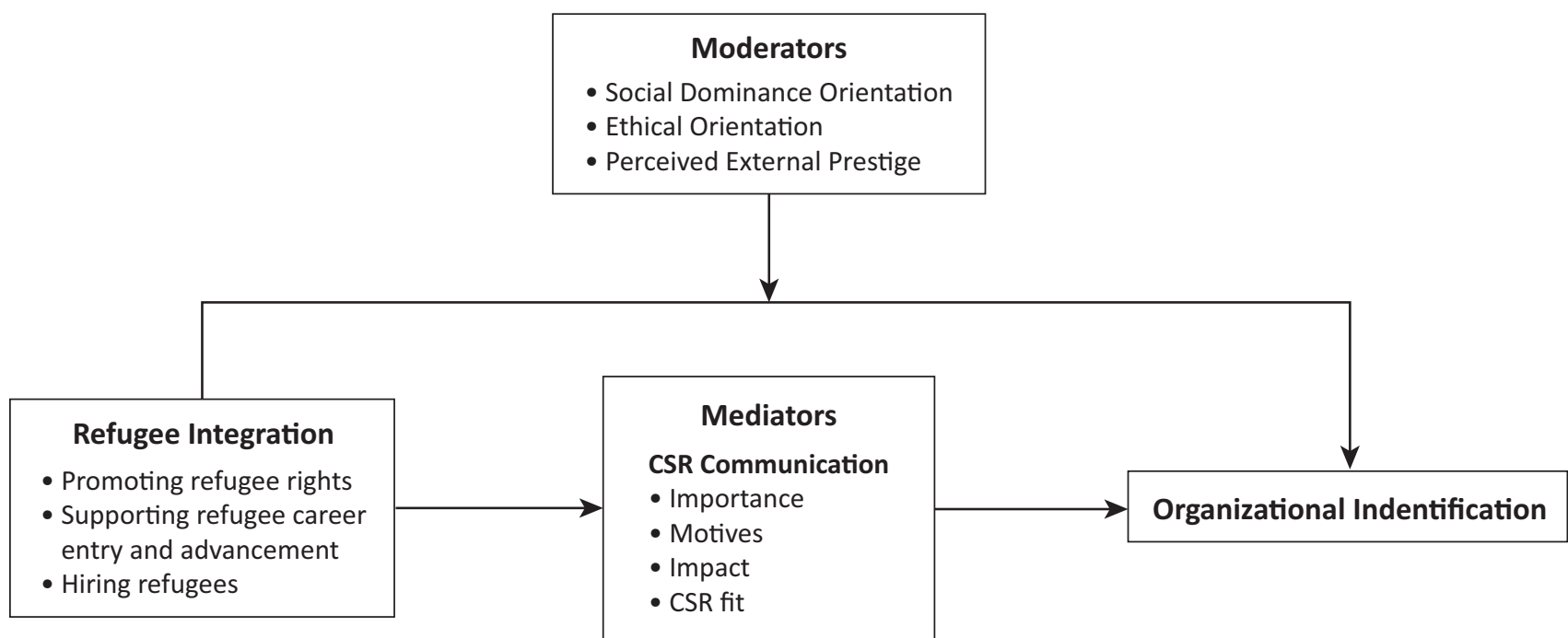

Figure 1. The mediating and moderating mechanisms of the relationship of refugee integration and organizational identification.

low among both internal and external stakeholders ( $\mathrm{Du}$, Bhattacharya, \& Sen, 2007). Without understanding why and how a company should contribute to refugee integration, employees are likely to question their employer's motivation to engage in this issue. Strong attributions of extrinsic motives (i.e., the company is seen as only attempting to increase its profits) will lead to unfavorable attitudes among stakeholders (e.g., employees) toward the company (Foreh \& Grier, 2003).

Another key challenge relates to how business may minimize employee skepticism and convey intrinsic motives (i.e., the company is seen as acting out of a genuine concern for the focal issue) for their CSR activities (Du, Bhattacharya, \& Sem, 2010). While employees claim they are interested in knowing about the good deeds of their employer, they also "quickly become leery of the CSR motives" if their employer aggressively promotes their CSR activities (Du et al., 2010, p. 9). Along with this line, if the value of creating a diversity corporate culture through employing refugees is not effectively communicated internally, employees may commit to a discrimination at the workplace (Colic-Peisker \& Tilbury, 2006). This challenge can disrupt refugee adaptation to the workplace, flowing on to negatively affect the corporate culture as well as other employees at work (Newman, Nielsen, Smyth, Hirst, \& Kennedy, 2018). Needless to say, the success of refugee employment and integration is contingent on overcoming these challenges, i.e., to raise awareness among employees and to manage their attributions towards a business firm's engagement in this issue. Therefore, in this section, we conceptualize the importance of CSR communication in the relationship of refugee integration and organization-employee identification. We also propose a multilevel framework, incorporating not only corporate-level factors (e.g., CSR communication and perceived external prestige [PEP]), but also employees' personal-level determinants (e.g., social dominance orientation [SDO] and ethnic identity), which may affect the relationship of refugee integration and organizational identification. We hope the proposed conceptual framework can be decisive in shifting refugee support as a novel and important CSR type from a discretionary activity to a more sustainable approach.

\subsection{Refugee Integration (CSR) and Organizational Identification}

Due to the desire to make a social contribution and the feeling of pride to work for a good citizen, employees may identify strongly with an organization which proactively engages in CSR (Rodrigo \& Arenas, 2008). Refugee employment and integration, if recognized by employees as valuable as other CSR initiatives (e.g., the adoption of clean energy, corporate philanthropy), will be desired to meet the social norms. Thus, for business firms with a clear claim on refugee support, employees are likely to value the endorsement of refugee employment and integration and perceive it as enforcing the organization's diversity culture while conforming to their own expectations.

Proposition 1: The endorsement of refugee employment and integration are valued by the employees and are positively associated with their identification with the organization.

\subsection{Mediating Mechanisms: The Role of Corporate Communication}

Employee identification with the organization is an active process that is mediated by communication, particularly the efforts of the organization in raising awareness and mitigating stakeholder (employee) skepticism of CSR, as well as showcasing the fit with organizational goals and 
the actual impact of CSR activities. First, the importance of refugee employment and integration as a social issue must be clearly communicated to internal stakeholders, in particular, if this engagement is not logically related to the company's business. By doing so, employees' concern about ulterior motives of their employer can be allayed to a certain extent (Menon \& Kahn, 2003).

Corporate communication can also focus on CSR motives with the purpose of reducing employee skepticism (Du et al., 2010). In practice, business firms vary as to extrinsic or intrinsic motives they communicate to internal stakeholders. Porter and Kramer (2006) argue that a company should draw on the convergence of social and business interests, while acknowledging the benefits of CSR endeavors to the company itself as well as to the society as a whole. Take Unilever for example, both aspects are clearly communicated on its corporate webpage with regard to helping address the refugee crisis in Europe:

Businesses can and must play an active role in helping address the refugee crisis, as the cost of inaction is greater than the cost of action. Doing so can help create jobs, raise the productivity and wages of local workers, lift capital returns, stimulate international trade and investment and boost innovation, enterprise and growth. (Unilever, 2017)

While both the importance and motives focus on the input side of corporate endeavor, the output side is also a key matter to communicate, that is, the actual impact (Du et al., 2010). As CSR communication often generates the impression of "bragging" nowadays (Sen, Du, \& Bhattacharya, 2009), to focus on factual social impact of a refugee integration endeavor may serve as supporting evidence confirming underlying motives of a company and thus is an effective communication strategy. Communicating about actual CSR impact affects employees' attitudes as well as behaviors towards their employer positively (Rupp, Ganapathi, Aguilera, \& Williams, 2006). Therefore, we conjecture that employees perceive "actual impact" valuable for judging the commitment of their employer. Unilever, for example, listed the refugee entrepreneurs who were chosen for their integration initiative and presented their personal perspectives about how they developed their career with this support (Unilever, 2018). The "real impact" of the refugee integration on people out of the refugee community (e.g., the business leaders) should be communicated as well.

Last but not the least, Du et al. (2010) argue that CSR fit, i.e., the perceived congruence between a social issue and the company's main business is also a vital factor to communicate. Employees may expect their employer to commit to refugee employment and integration if these social issues have a logical association with corporate core activities. Simmons and Becker-Olsen (2006) show that without a clear logical connection between a social issue and a company's main business, stakeholders are likely to attribute corporate engagement in the social issue to extrinsic motives and thus react negatively to it. Therefore, in CSR communication, a company should provide sufficient information with respect to the rationale for its refugee employment and integration, in order to achieve a perceived fit.

In summary, in the context of refugee employment and integration, corporate communication plays an important role in reducing employee skepticism. This role is in particular relevant to the business firms which made a clear standpoint in public that they are in support of integrating refuges at the workplace. The importance and motives of the endeavor, actual impact as well as the fit of the social issue and a company's core acidifies are identified as important factors to be addressed in corporate communication. They will mediate the positive impact of refugee integration on employee identification.

Proposition 2: The impact of the endorsement of refugee employment and integration on employee identification will be mediated by the extent to which the importance, motives, actual impact and fit of this endeavor is communicated within an organization.

\subsection{The Moderating Roles of Perceived External Prestige, Social Dominance Orientation and Ethnic Identity}

Parallel to CSR communication, PEP is a relevant corporate-level factor to consider in the context of refugee employment and integration. It entails how employees perceive outsiders view their organization as well as themselves as a member of it (Dutton et al., 1994; Mignonac \& Herrbach, 2004). It is contrary to "organizational associations" (Brown, Dacin, Pratt, \& Whetten, 2006), or "organizational identity" (Dutton et al., 1994), which employees form directly from attributes of an organization. When employees believe that important outsiders, such as investors, customers, governments or the general public, see their employer in a positive light, they will feel proud to belong to the organization (Mael \& Ashforth, 1992; Smidts, Pruyn, \& Van Riel, 2001). The positive impact of PEP on employee identification has been found in empirical studies. For example, Bhattacharya, Rao and Glynn (1995) show that identifying with an organization enhances an individual's self-esteem. Thus, the more prestigious an organization is perceived by its employees, the greater the potential boost to self-esteem through identification.

PEP may be built by a variety of sources such as wordof-mouth, publicity, company-controlled external information and even internal communication about how the company is thought by external people and entities (Smidts et al., 2001). In the context of CSR, Kim, Lee, Lee and Kim (2010) argue that with these sources, employees will formulate their perceptions of the organization's CSR activities, while comparing the PEP of their employer with that of other business firms. In the refugee integration context, if an organization's CSR effort is considered 
as central, enduring, distinctive and superior to others', employees will perceive their employer with a strong PEP. Thus, they will feel rewarded to be a member of a socially valued company and the resulting self-esteem will trigger a higher degree of identification (Dutton et al., 1994; Kim et al., 2010) and, accordingly, higher commitment to supporting refugee integration, relative to a firm with lower PEP.

Proposition 3: PEP moderates the impact of the endorsement of refugee employment and integration on employee identification. The endeavor of an organization with a strong PEP will be assessed by its employees more positively than an organization with a low PEP.

In addition to the corporate-level factors summarized in Proposition 2 and 3, how the refugee employment and integration endeavor of a business firm will lead to employee identification is also determined by employees' individual beliefs. In particular, two important factors that shape employees' attitudes and perceptions and are likely to moderate the linkage of refugee integration and organizational identification include: SDO and ethnic identity.

The social dominance theory refers to SDO as a "general attitudinal orientation toward inter-group relations, reflecting whether one generally prefers such relations to be equal, versus hierarchical" (Pratto, Sidanius, Stallworth, \& Malle, 1994, p. 742). SDO argues that discrimination of different social groups is triggered by the same psychological background and appears in a similar pattern in all kinds of societies (Sidanius \& Pratto, 2003). Despite so, people's attitudes toward group equality versus group dominance is different (Sidanius \& Pratto, 2003). It implies that while some people see inequality as normal and consider certain societal groups as better than others, others however may favor social equality. It is a personality trait predicting individuals' preference for specific social and organizational settings (Haley \& Sidanius, 2005). SDO is relevant in the context of refugee integration particularly in light of the often-negative perceptions of refugees, for example in terms of job loss at the organizational as well as societal level. Accordingly, within business firms, employees with high SDO may tend to promote intergroup hierarchies and to rank social groups in a superior-inferior hierarchy (Snellman \& Ekehammar, 2005). Pratto and Lemieux (2001) further investigated SDO with respect to the ambiguity towards immigration. They argue that the refugee integration policy, for example, may bring out people' prejudicial aggressive natures. As a consequence, employees with high SDO are unlikely to find a corporate policy aiming at increasing equality between groups (e.g., integration employment and integration) appealing to them, in comparison to employees who are low on SDO.

Although some scholars have criticized the social dominance theory for displaying human as "primitive hordes at constant war with each other" and suggested that in human history, people have shown mutual respect and unity, as opposed to dominating one another (Turner \& Reynolds, 2003, p. 200), the relevance of SDO in explaining the context of immigration and refugee crisis is confirmed in literature (Pratto \& Lemieux, 2001). Along this line, we argue that SDO moderates the linkage of refugee integration and employee identification: As high-SDO employees are in favor of intergroup hierarchies and intend to rank social groups in a superiorinferior hierarchy, they will assess their employer's endeavors in employing and supporting refuges less positively than low-SDO employees.

Proposition 4: SDO moderates the impact of the endorsement of refugee employment and integration on employee identification. Employees high in SDO assess their employer's endeavor less positively than employees low in SDO.

A second factor to consider is ethnic identity, defined by Tajfel (1981) as the "part of an individual's self-concept which derives from [one's] knowledge of [one's] membership of a social group (or groups) together with the value and emotional significance attached to that membership" (Tajfel, 1981, p. 255). Accordingly, it is considered as part of an individual's self-concept emerged from one's knowledge of his/her own ethnic group, as well as the values attached to membership of that group (Lee \& Yoo, 2004; Newman et al., 2018). As a key aspect of an individual's social identity, ethnic identity not only fosters an individual's sense of belong to his/her ethnic group, it also leads an individual to make a conscious effort to learn about his/her ethnic group (Yoo \& Lee, 2008). Empirical work has found that refugees from the Middle East often hold a strong ethnic identity, partially because of their cultures which are with high levels of collectivism and partially due to the trauma and negative experiences resulted from the individual's refugee status (Hattrup, Ghorpade, \& Lackritz, 2007; Newman et al., 2018). In contrast, individuals who are born in individualistic cultures are less sensitive about their ethnic identity and thus less eager to connect to others with the same cultural background and beliefs.

Yet, recent studies on ethnical identity in the context of organizational diversity communication conclude that individual's ethnic identity shapes their response to corporate diversity policy. Individuals with high ethnic identity will respond more negatively to discrimination than those with low ethnic identity (Downey \& Feldman, 1996) and thus more positively to organizational policies and practices that support diversity (Newman et al., 2018). As employees high in ethnic identity are more sensitive to racial discrimination, an organizational culture in which diversity is valued and cultural differences are respected is likely to resonate more positively with them, in comparison to other employees with a low ethnic identity (Newman et al., 2018). Refugee employment and 
integration as part of corporate diversity culture, thus, would make employees with strong ethical identity develop more positive attributions for things that happen to them at work. As a consequence, they will identify more strongly with their employer, as opposed to those low in, ethnic identity.

Proposition 5: Ethnic identity moderates the impact of the endorsement of refugee employment and integration on employee identification. Employees with a strong ethnic identity assess their employer's endeavor more positively than employees with a low ethnic identity.

\section{Conclusion}

In this conceptual article, we have theorized the role of business in supporting and advancing refugee integration, specifically, economic or labor market orientation. We posit that business responsibility toward the ongoing refugee crisis stems from its (influential) position as a societal actor; however, we contend that a sustainable business case for refugee integration rests on the support and engagement of a key stakeholder aka employees.

In light of the yet limited theorizing on business involvement in the refugee crisis, our article contributes by adding the perspective of employees in business organizations that have made an explicit commitment to supporting refugees as a form of CSR. Considering the perspective of employees and the (potential) consequences on organization-employee identification can serve as a basis for future empirical research. Such a perspective shifts the often-disproportionate emphasis on refugees' (own) responsibility for economic integration, for example, through the acquisition of language skills, toward understanding organizational attitudes towards refugee integration (e.g., Lundborg \& Skedinger, 2016).

Further, we conceptualized a multilevel framework, combining the role of corporate-level factors (e.g., CSR communication and PEP) and personal-level factors (e.g., SDO and ethnic identity) in mediating and moderating the relationship of refugee integration and organizational identification, respectively. Such an endeavor is the first to link refugee integration literature and the CSR communication literature through developing a conceptual model.

Our arguments rest on the current state of business involvement, which is rather sporadic and ad-hoc, led by a few large, multinational, organizations (MNCs) that have made an explicit commitment to supporting refugees. We recognize that there may be smaller, regional or local organizations that play a vital role in this domain and/or that their approach to refugee support may be decisively different from that of multinationals; paradoxically, these organizations may not enjoy the same visibility and attention as large organizations. On the one hand, by taking the lead on refugee integration (as select examples in the article illustrate), large orga- nizations may serve as an example for others. On the other, we do not undermine the importance of other organizations, particularly small and medium enterprises (SMEs), that constitute a sizable proportion of employers especially in Europe. Using our conceptual model, researchers may conduct empirical research among SMEs that have made an explicit commitment to refugee support and compare results with that of MNCs. Likewise, given the scope of our article, we are unable to focus on entrepreneurship as an example of "bottom up" refugee innovation (Betts, 2014), efforts that are equally valuable as solutions for integration and economic self-reliance.

Our focus in this conceptual piece is on the organizational, specifically employee, perspective. Even when business may principally agree with the call to actively promote labor market integration of refugees, the translation to practice may be challenging for the multitude of reasons noted early on. While more have joined forces in recent years, for example, UNHCR's \#WithRefugees coalition, these efforts are inadequate given the scale of the refugee crisis. Moreover, the need of the hour is to formulate long-term solutions in which the private sector is deemed "an essential partner" (Martinez, 2018).

Guided by the goal of advancing sustainable solutions around business involvement in refugee integration, we conjecture that the success of refugee employment and integration is contingent on managing employees' attributions toward a business firm's engagement in this issue. The effectiveness of CSR communication plays an important role in garnering support and reducing employee skepticism. We suggest that the importance and motives of the endeavor, actual impact, as well as the fit of the social issue with a company's core activities are four important factors to be addressed in corporate communication. They may mediate the positive impact of refugee integration on employee identification.

Simultaneously, how the refugee employment and integration endeavor of a business firm will lead to employee identification is also determined by employees' individual beliefs, in particular, SDO and ethnic identity. These are likely to moderate the linkage of refugee integration and employee identification. Leveraging on the conceptual framework, further research may focus on testing the mediating and moderating mechanisms of the relationship of refugee integration and organizational identification empirically through collecting field data from business firms.

Important to note is that both at the corporate and the individual level, one might expect that cultural and contextual differences (e.g., integration policies, societal attitudes) across EU states will likely shape the specific manifestations of refugee support, as well as the response to it. Although we focus on large multinationals with an expressed commitment to refugee integration as a form of CSR, no business exists in isolation from its social context. How a business communicates its rationale for supporting refugee integration is an important and complementary goal that can further advance 
the understanding of CSR communication outlined in our model. The conceptual model may also form the basis for future experiments to assess the impact of specific mechanisms (e.g., CSR communication) on organizationemployee identification.

\section{Acknowledgments}

We are grateful to guest editors Vasiliki Tsagkroni and Amanda Alencar and the anonymous reviewers for their invaluable feedback and guidance. Both authors contributed to this article equally.

\section{Conflict of Interests}

The authors declare no conflict of interests.

\section{References}

Ager, A., \& Strang, A. (2008). Understanding integration: A conceptual framework. Journal of Refugee Studies, 21(2), 166-191.

B-Team. (2016, October 20). New report: Refugees are an opportunity for humanity. B-Team. Retrieved from http://www.bteam.org/announcements/newreport-refugees-are-an-opportunity-for-humanity

Bauman, C. W., \& Skitka, L. J. (2012). Corporate social responsibility as a source of employee satisfaction. $R e$ search in Organizational Behavior, 32, 63-86.

Betts, A. (2014). Refugees and innovation. Forced Migration Review, 2014. Retrieved from https://www. fmreview.org/innovation/contents

Betts, A., \& Buith, J. (2017). Talent displaced: The economic lives of Syrian refugees in Europe. Survey by Deloitte and Refugees Studies Center. Deloitte. Retrieved from https://www2.deloitte.com/global/en/ pages/about-deloitte/articles/talent-displaced.html

Bhattacharya, C. B., Rao, H., \& Glynn, M. A. (1995). Understanding the bond of identification: An investigation of its correlates among art museum members. The Journal of Marketing, 59(4), 46-57.

Bhattacharya, C. B., Sen, S., \& Korschun, D. (2007). Corporate social responsibility as an internal marketing strategy. MIT Sloan Management Review, 49(1), 1-29.

Bhattacharya, C. B., Sen, S., \& Korschun, D. (2008). Using corporate social responsibility to win the war for talent. MIT Sloan Management Review, 49(2), 37-44.

Brown, T. J., Dacin, P. A., Pratt, M. G., \& Whetten, D. A. (2006). Identity, intended image, construed image and reputation: An interdisciplinary framework and suggested terminology. Journal of the Academy of Marketing Science, 34(2), 99-106.

Brunton, M., Eweje, G., \& Taskin, N. (2015). Communicating corporate social responsibility to internal stakeholders: Walking the walk or just talking the talk? Business Strategy and the Environment, 26(1), 31-48.
The International Rescue Committee. (n.d.). Business Refugee Action Network. The International Rescue Committee. Retrieved from https://www.rescue-uk. org/Business

Carroll, A. B., \& Shabana, K. M. (2010). The business case for corporate social responsibility: A review of concepts, research and practice. International Journal of Management Reviews, 12, 85-105.

Colic-Peisker, V., \& Tilbury, F. (2006). Employment niches for recent refugees: Segmented labour market in twenty-first century Australia. Journal of Refugee Studies, 19(2), 203-229.

Cone Communications. (2016, November 2). Threequarters of millennials would take a pay cut to work for a socially responsible company, according to the research from Cone Communications. Cone Communications. Retrieved http://www.conecomm.com/ news-blog/2016-cone-communications-millennialemployee-engagement-study-press-release

Deloitte. (2017). Deloitte Millennial Survey. Deloitte. Retrieved from https://www2.deloitte.com/il/en/ pages/about-deloitte/articles/millennialsurvey.html

Downey, G., \& Feldman, S. I. (1996). Implications of rejection sensitivity for intimate relationships. Journal of Personality and Social Psychology, 70(6), 1327-1343.

Du, S., Bhattacharya, C. B., \& Sen, S. (2007). Reaping relational rewards from corporate social responsibility: The role of competitive positioning. International Journal of Research in Marketing, 24(3), 224-241.

Du, S., Bhattacharya, C. B., \& Sen, S. (2010). Maximizing business returns to corporate social responsibility (CSR): The role of CSR communication. International Journal of Management Reviews, 12(1), 8-19.

Dutton, J. E., Dukerich, J. M., \& Harquail, C. V. (1994). Organizational images and member identification. Administrative Science Quarterly, 39(2), 239-263.

European Commission. (2011). Corporate social responsibility \& responsible business conduct. Europa. Retrieved from https://ec.europa.eu/growth/industry/ corporate-social-responsibility_en

European Commission. (2017). A European partnership for integration. Europa. Retrieved from https://ec.europa.eu/home-affairs/sites/home affairs/files/e-library/documents/policies/legalmigration/integration/docs/20171220_european_ partnership_for_integration_en.pdf

Foreh, M. R., \& Grier, S. (2003). When is honesty the best policy? The effect of stated company intent on consumer skepticism. Journal of Consumer Psychology, 13(3), 349-356.

Haley, H., \& Sidanius, J. (2005). Person-organization congruence and the maintenance of group-based social hierarchy: A social dominance perspective. Group Processes \& Intergroup Relations, 8(2), 187-203.

Haski-Leventhal, D., Roza, L., \& Meijs, L. C. (2017). Congruence in corporate social responsibility: Connecting the identity and behavior of employers and employees. Journal of Business Ethics, 143(1), 35-51. 
Hatch, M. J., \& Schultz, M. (2004). Organizational identity: A reader. Oxford: Oxford University Press.

Hattrup, K., Ghorpade, J., \& Lackritz, J. R. (2007). Work group collectivism and the centrality of work a multinational investigation. Cross-Cultural Research, 41(3), 236-260.

loannou, I. (2015, September 29). The refugee crisis and the boundaries of corporate responsibility. Forbes. Retrieved from https://www.forbes.com/ sites/lbsbusinessstrategyreview/2015/09/29/therefugee-crisis-and-the-boundaries-of-corporateresponsibility/\#61be639e613b

Kim, H. R., Lee, M., Lee, H. T., \& Kim, N. M. (2010). Corporate social responsibility and employee-company identification. Journal of Business Ethics, 95(4), 557-569.

Koser, K. (2013). Making the business case for migration. In I. Sola (Ed.), The business case for migration (World of Economic Forum Report, No. 140913). Cologny: World of Economic Forum. Retrieved from http://www3.weforum.org/docs/GAC/2013/WEF_ GAC_Migration_BusinessCase_Report_2013.pdf

Lee, R. M., \& Yoo, H. C. (2004). Structure and measurement of ethnic identity for Asian American college students. Journal of Counseling Psychology, 51(2), 263-269.

Lundborg, P., \& Skedinger, P. (2016). Employer attitudes towards refugee immigrants: Findings from a Swedish survey. International Labour Review, 155(2), 315-337.

Mael, F., \& Ashforth, B. E. (1992). Alumni and their alma mater: A partial test of the reformulated model of organizational identification. Journal of Organizational Behavior, 13(2), 103-123.

Marcus, L. P. (2015, September 11). Europe's refugee crisis is a major opportunity for businesses. The Guardian. Retrieved from https://www.theguardian. com/business/2015/sep/11/europes-refugee-crisisis-a-major-opportunity-for-businesses

Martinez, M. (2018, September 26). More businesses commit to helping refugees thrive with new jobs, trainings, investment. UNHCR. Retrieved from https://www.unhcr.org/news/latest/2018/9/ 5 babbecf4/businesses-commit-helping-refugeesthrive-new-jobs-trainings-investment.html

Menon, S., \& Kahn, B. E. (2003). Corporate sponsorships of philanthropic activities: When do they impact perception of sponsor brand? Journal of Consumer Psychology, 13(3), 316-327.

Mignonac, K., \& Herrbach, O. (2004). Linking work events, affective states and attitudes: An empirical study of managers' emotions. Journal of Business and Psychology, 19(2), 221-240.

Newman, A., Nielsen, I., Smyth, R., Hirst, G., \& Kennedy, S. (2018). The effects of diversity climate on the work attitudes of refugee employees: The mediating role of psychological capital and moderating role of ethnic identity. Journal of Vocational Behavior, 105,
147-158.

OECD, \& UNHCR. (2016). Hiring refugees: What are the opportunities and challenges for employers? Migration Policy Debates, 10. Retrieved from https://www. oecd.org/els/mig/migration-policy-debates-10.pdf

OECD, \& UNHCR. (2018). Engaging with employers in the hiring of refugees. Paris and Geneva: OECD and UNHCR. Retrieved from http://www.oecd.org/els/ $\mathrm{mig} / \mathrm{UNHCR}$-OECD-Engaging-with-employers-inthe-hiring-of-refugees.pdf

Okoye, A. (2009). Theorising corporate social responsibility as an essentially contested concept: Is a definition necessary? Journal of Business Ethics, 89, 613-627.

Podnar, K., Golob, U., \& Jančič, Z. (2011). Identification with an organisation as a dual construct. European Journal of Marketing, 45(9/10), 1399-1415.

Porter, M., \& Kramer, M. (2006). Strategy \& society: The link between competitive advantage and corporate social responsibility. Harvard Business Review, 84(12), 78-92.

Pratto, F., \& Lemieux, A. F. (2001). The psychological ambiguity of immigration and its implications for promoting immigration policy. Journal of Social Issues, 57(3), 413-430.

Pratto, F., Sidanius, J., Stallworth, L. M., \& Malle, B. F. (1994). Social dominance orientation: A personality variable predicting social and political attitudes. Journal of Personality and Social Psychology, 67(4), 741-763.

Riketta, M. (2005). Organizational identification: A meta-analysis. Journal of Vocational Behavior, 66(2), 358-384.

Rodrigo, P., \& Arenas, D. (2008). Do employees care about CSR programs? A typology of employees according to their attitudes. Journal of Business Ethics, 83(2), 265-283.

Rupp, D. E., Ganapathi, J., Aguilera, R. V., \& Williams, C. A. (2006). Employee reactions to corporate social responsibility: An organizational justice framework. Journal of Organizational Behavior, 27(4), 537-543.

Rupp, D. E., \& Mallory, D. B. (2015). Corporate social responsibility: Psychological, person-centric and progressing. Annual Review of Organizational Psychology and Organizational Behavior, 2, 211-236.

Scholten, P., Baggerman, F., Dellouche, L., Kampen, V., Wolf, J., \& Ypma, R. (2017). Policy innovation in refugee integration? A comparative analysis of innovative policy strategies towards refugee integration in Europe. Rotterdam: Dutch Department of Social Affairs and Employment. Retrieved from https://www.rijksoverheid.nl/binaries/ rijksoverheid/documenten/rapporten/2017/11/ 03/innovatieve-beleidspraktijken-integratiebeleid/ Policy+innovation+in+refugee+integration.pdf

Sen, S., Du, S., \& Bhattacharya, C. B. (2009). Building relationships through corporate social responsibility. In D. J. MacInnis, C. W. Park, \& J. R. Priester (Eds.), Handbook of brand relationships (pp. 195-211). Armounk, 
NY: M. E. Sharpe.

Serafeim, G. (2015, April 14). The type of socially responsible investments that make firms more profitable. Harvard Business Review. Retrieved from https:// hbr.org/2015/04/the-type-of-socially-responsibleinvestments-that-make-firms-more-profitable

Sidanius, J., \& Pratto, F. (2003). Social dominance theory and the dynamics of inequality: A reply to Schmitt, Branscombe, \& Kappen and Wilson \& Liu. British Journal of Social Psychology, 42(2), 207-213.

Simmons, C. J., \& Becker-Olsen, K. L. (2006). Achieving marketing objectives through social sponsorships. Journal of Marketing, 70(4), 154-169.

Smidts, A., Pruyn, A. T. H., \& Van Riel, C. B. (2001). The impact of employee communication and perceived external prestige on organizational identification. Academy of Management Journal, 44(5), 1051-1062.

Snellman, A., \& Ekehammar, B. (2005). Ethnic hierarchies, ethnic prejudice and social dominance orientation. Journal of Community \& Applied Social Psychology, 15(2), 83-94.

Tajfel, H. (1981). Human groups and social categories. Cambridge, MA: Cambridge University Press.

Tomlinson, F., \& Egan, S. (2002). From marginalization to (dis)empowerment: Organizing training and employment services for refugees. Human Relations, 55(8), 1019-1043.

Turner, J. C., Brown, R. J., \& Tajfel, H. (1979). Social comparison and group interest in ingroup favouritism. Eu- ropean Journal of Social Psychology, 9(2), 187-204.

Turner, J. C., \& Reynolds, K. J. (2003). Why social dominance theory has been falsified. British Journal of Social Psychology, 42(2), 199-206.

Unilever. (2017, June 20). The role business can play in tackling the refugee crisis. Unilever. Retrieved from https://www.unilever.com/news/news-andfeatures/Feature-article/2017/role-business-canplay-in-tackling-the-refugee-crisis.html

Unilever. (2018, June 20). Three innovative ways we help employees....and they help us. Unilever. Retrieved from https://www.unilever.com/news/news-andfeatures/Feature-article/2018/three-innovativeways-we-help-refugee-and-they-help-us.html

Vision Europe Summit. (2016). Improving the responses to the migration and refugee crisis in Europe. Vision Europe. Retrieved from https://static1.squarespace. com/static/54c95cbee4b03749141be705/t/ 5829f2b69de4bb1fe2fd5c0e/1493035163216/ Improving+the+Responses+to+the+Migration+and+ Refugee+Crisis+in+Europe.pdf

Yoo, H. C., \& Lee, R. M. (2008). Does ethnic identity buffer or exacerbate the effects of frequent racial discrimination on situational well-being of Asian Americans? Journal of Counseling Psychology, 55(1), 63-74.

Zraick, K. (2018, December 5). Lego Foundation and Sesame Street team up to help refugee children. The New York Times. Retrieved from https://www. nytimes.com/2018/12/05/world/lego-sesamestreet-refugees.html

\section{About the Authors}

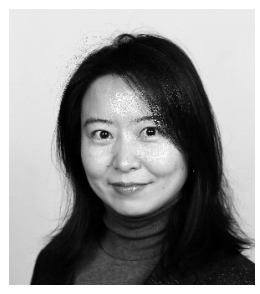

Yijing Wang is Assistant Professor in the Department of Media and Communication at Erasmus University Rotterdam. She obtained a PhD degree in Corporate Reputation and Stakeholder Management from Rotterdam School of Management (RSM), Erasmus University Rotterdam. Her research focuses on corporate reputation and stakeholder management, crisis communication, managing sustainability and corporate branding. She is also interested in the broader question of why and how an intangible asset can generate a superior financial or social performance to a firm.

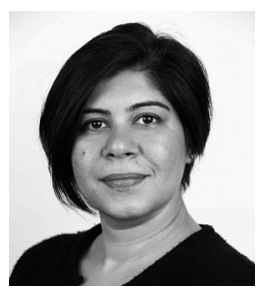

Vidhi Chaudhri (PhD Purdue University, USA) is Assistant Professor in the Department of Media and Communication at Erasmus University Rotterdam. Her teaching and research interests span corporate social responsibility (CSR), social media, crisis communication and corporate reputation and digital activism. She has published in international peer-reviewed journals such as Management Communication Quarterly, Public Relations Review, Social Movement Studies and International Journal of Business Communication, among others. She is also co-author of Corporate Communication through Social Media: Strategies for Managing Reputation (SAGE). 